\title{
DROPLET DISTRIBUTION AS A FUNCTION OF COTTON INTERROW SPACING AND ANGLES OF SPRAYER DISPLACEMENT
}

\author{
Izidro dos S. de Lima Junior ${ }^{*}$, Paulo E. Degrande ${ }^{2}$, Cristiano M. A. de Souza ${ }^{2}$, \\ Antonio L. Viegas Neto ${ }^{3}$
}

${ }^{1 *}$ Corresponding author. Instituto Federal de Mato Grosso do Sul (IFMS)/ Ponta Porã - MS, Brasil.

E-mail: izidro.lima@ifms.edu.br

\section{KEYWORDS}

application

technology, droplet

deposition, third of plants.

\begin{abstract}
Application technology factors may be influenced by changes in plant architecture, such as height and leaf area. This study aimed to evaluate which angle of sprayer displacement in the application of pesticides in relation to the direction of cotton sowing, cultivated in the ultra-narrow row, narrow row, and conventional systems, provides the best application quality characteristics in the different thirds of plants. The experiment was installed in a split-plot design with four replications in the $3 \times 4$ factorial scheme, composed of three cotton cultivation systems and four angles of sprayer displacement in relation to the direction of the sowing rows. The evaluated characteristics were mean volumetric diameter, density and coverage of droplets, number of droplets, and open area in the interrows without leaf. The upper third presented the highest values of mean volumetric diameter, number of droplets, and density and coverage of droplets for all interrow spacing and application angles. The angle of displacement of $30^{\circ}$ in relation to the sowing row presented the best results in relation to the number and density of droplets. The spacing of $0.90 \mathrm{~m}$ in the interrows increased the number of droplets, droplet density, and coverage in the lower third of plants.
\end{abstract}

\section{INTRODUCTION}

Brazil is the fifth world's largest cotton producer. In the 2016/2017 season, Brazil produced 1.6 million tons of fiber and the Midwest region accounted for approximately $65 \%$ of the total Brazilian production (Conab, 2018). With the emergence of new varieties and the purpose of reducing crop costs, several have been carried out to implement reduced interrow spacings, called ultra-narrow row (0.19 to $0.38 \mathrm{~m})$, narrow row $(0.39$ to $0.76 \mathrm{~m})$, and conventional $(<0.76 \mathrm{~m})$ (Borin et al., 2017).

Plant arrangement in the cultivation area is modified with the alteration in the interrow spacing, being expected changes in the morphological characteristics of plants, such as number and size of leaves, stem diameter, height of first reproductive branch, plant height, and dry matter accumulation during plant development (Rosolem et al., 2012).

The morphological characteristics of plants can affect the quality of pesticide application since application technology factors, such as jet trajectory, application uniformity, number of droplets, droplet diameter, droplets reaching the target, droplet evaporation, and drift, can be influenced by changes in plant architecture, such as height and leaf area (Cunha et al., 2008; Cunha et al., 2018), as occurs in the ultra-narrow row and narrow row cultivation systems in relation to the conventional cultivation system.

The distribution of spray droplets, using spray tips that produce mostly fine or large droplets, occurs primarily in the upper third of plant canopy. Droplet deposition in the different parts of plant canopy is studied in relation to tip models, presence or absence of air induction in the tips, tip angles in the spray boom, addition of adjuvants, terrestrial or aerial application, application volume (França et al., 2018), but few studies on the direction of sprayer displacement in relation to the crop rows.

Terrestrial or aerial pesticide application is performed to achieve the highest sprayer efficiency, with the least number of maneuvers of the tractor-sprayer unit, self-propelled sprayer or airplane. Thus, a factor that is not taken into account at the time of application is the sprayer displacement in relation to the arrangement of sowing rows

\footnotetext{
${ }^{2}$ Universidade Federal da Grande Dourados (UFGD)/ Dourados - MS, Brasil.

${ }^{3}$ Instituto Federal de Mato Grosso do Sul (IFMS)/ Ponta Porã - MS, Brasil.

Received in: 7-5-2018

Accepted in: 10-8-2018
} 
since the application can occur in the direction, transversal or at an angle to the sowing row (Graziano et al., 2017).

This study aimed to evaluate which angle of sprayer displacement in relation to the direction of cotton sowing, cultivated in the ultra-narrow row, narrow row, and conventional systems, provides the best application quality characteristics.

\section{MATERIAL AND METHODS}

This study was carried out at the Experimental Farm of Agricultural Sciences (FAECA) of the Federal University of Grande Dourados (UFGD) in Dourados, MS, Brazil, in the 2010/2011 and 2011/2012 seasons.

The soil in this area is classified as a clayey textured Oxisol (Latossolo Vermelho Distroférrico, Brazilian Soil Classification System) originally under Cerrado vegetation. Dourados is located at the geographical coordinated $22^{\circ} 13^{\prime} 16^{\prime \prime} \mathrm{S}$ and $54^{\circ} 17^{\prime} 01^{\prime \prime} \mathrm{W}$, with an altitude of $430 \mathrm{~m}$. According to Köppen classification, the regional climate is classified Cwe, i.e. a humid mesothermal climate with an average annual temperature varying from 20 to $24{ }^{\circ} \mathrm{C}$ and an average annual precipitation ranging from 1250 to 1500 $\mathrm{mm}$.

For experiment setup, a cotton area of 2.0 ha was grown in three different cultivation systems: ultra-narrow row, narrow row, and conventional. In the 2010/2011 season, sowing was performed on December 26, 2010, and the emergence occurred on January 2, 2011, while in the $2011 / 2012$ season, sowing was carried out on November 15 , 2011, and the emergence occurred on November 22, 2011. The cultivar used to perform the experiment was FMT 701 in the 2010/2011 season and NuOpal RR in the 2011/2012 season, with a sowing density of nine seeds per linear meter. After germination, the population found was eight plants per linear meter in the three cultivation systems.

Crop management followed the recommendations of Embrapa (2011). In the first season, experiment setup was carried out on March 13, 2011, i.e. at 71 days after emergence and phenological stage F2. In the second season, the experiment setup was carried out on January 1, 2012, i.e. at 89 days after emergence and phenological stage F2 (Marur \& Ruano, 2001).

The experiment was installed in a split-plot design with 4 replications in a $3 \times 4$ factorial scheme, composed of three cotton cultivation systems (plot) and four angles of sprayer displacement (subplot) in relation to the direction of the sowing rows. Cultivation systems were divided in relation to the interrow spacing $(0.22,0.45$, and $0.90 \mathrm{~m})$. The angles of sprayer displacement were divided into $0^{\circ}$ (parallel to the crop row), $30^{\circ}$ (diagonal to the crop row), $45^{\circ}$ (diagonal to the crop row), and $90^{\circ}$ (perpendicular to the crop row) (Table 1$)$.

TABLE 1. Characterization of treatments, plant population, interrow spacing, and angle of sprayer displacement (AD). Dourados, MS, Brazil. 2013.

\begin{tabular}{|c|c|c|c|c|}
\hline Treatment & Plant population $\mathrm{ha}^{-1}$ & Cultivation system & Interrow spacing $(\mathrm{m})$ & $\hat{\mathrm{AD}}$ \\
\hline 1 & 300,000 & Ultra-narrow row & 0.22 & $0^{\circ}$ \\
\hline 2 & 300,000 & Ultra-narrow row & 0.22 & $30^{\circ}$ \\
\hline 3 & 300,000 & Ultra-narrow row & 0.22 & $45^{\circ}$ \\
\hline 4 & 300,000 & Ultra-narrow row & 0.22 & $90^{\circ}$ \\
\hline 5 & 200,000 & Narrow row & 0.45 & $0^{\circ}$ \\
\hline 6 & 200,000 & Narrow row & 0.45 & $30^{\circ}$ \\
\hline 7 & 200,000 & Narrow row & 0.45 & $45^{\circ}$ \\
\hline 8 & 200,000 & Narrow row & 0.45 & $90^{\circ}$ \\
\hline 9 & 100,000 & Conventional & 0.90 & $0^{\circ}$ \\
\hline 10 & 100,000 & Conventional & 0.90 & $30^{\circ}$ \\
\hline 11 & 100,000 & Conventional & 0.90 & $45^{\circ}$ \\
\hline 12 & 100,000 & Conventional & 0.90 & $90^{\circ}$ \\
\hline
\end{tabular}

At 45 days after plant emergence, the route through which the lift-mounted sprayer made the passes with the respective angles of displacement was performed.

A tractor with a front and rear tread width of $1.58 \mathrm{~m}$ and a lift-mounted sprayer provided with $13.0 \mathrm{~m}$ operational width booms were used for spraying. Spray nozzle assemblies were spaced every $0.50 \mathrm{~m}$. The spray nozzle used in the 2010/2011 season was the JA-2, black color, which produces a hollow-cone jet regulated for an application volume of $100 \mathrm{~L} \mathrm{ha}^{-1}$. The relative air humidity (RH) was $61 \%$ at the beginning of the application and $68 \%$ at the end of the application and the air speed was $3.5 \mathrm{~km}$ $\mathrm{h}^{-1}$ throughout the application.

In the 2011/2012 season, the spray nozzle used was a Teejet XR 110.02 VP, with a flat jet and regulated for an application volume of $120 \mathrm{~L} \mathrm{ha}^{-1}$. The relative air humidity (RH) was $75 \%$ at the beginning of the application and $86 \%$ at the end of the application and the air speed was $3.0 \mathrm{~km}$ $\mathrm{h}^{-1}$ throughout the application.
Water-sensitive papers were installed in the adaxial part of plant leaves for the analysis of the application technology. These water-sensitive papers were manufactured by the Novartis Biociências S.A. and had a yellow color that turns into blue upon receiving the impact of the droplet. At the time of pesticide application, plants were divided equally into three parts in the vertical direction and a water-sensitive paper was placed on each of these parts. After spraying, these papers were scanned in a digital equipment for studying the droplet spectrum by means of the E-sprinkle image analysis program. The number of droplets in the papers was evaluated.

The mean volumetric diameter (MVD) $(\mu \mathrm{m})$, number of droplets per $\mathrm{cm}^{2}$ (NOD), density of droplets per $\mathrm{cm}^{2}(\mathrm{DEN})$, the percentage of droplet coverage (COV), and the open area in the interrows without leaf were evaluated on the application day. To evaluate the open area, the area without leaf coverage was measured with a measuring tape. Three samples were taken per plot. 
The data were submitted to analysis of variance $(\mathrm{F}-$ test) and the means were compared by the Tukey's at $5 \%$ probability level.

\section{RESULTS AND DISCUSSION}

The mean volumetric diameter, droplet density, number of droplets, and droplet coverage showed a significant difference regarding the third of plants. The angle of $30^{\circ}$ presented the highest droplet density, differing statistically from the other treatments considering all the interrow spacings. The variables VMD, NOD, and COV did not differ statistically in relation to the application angle (Table 2).

The variables MVD, DEN, NOD, and COV presented the highest values in the upper third of cotton plants. The middle third differentiated from the lower third in DEN, NOD, and COV, while for MVD, the middle and lower thirds did not differ statistically (Table 2). The upper third of plants have the highest values for spraying rates since this location is the most exposed and unimpeded for spraying (Graziano et al., 2017).

TABLE 2. Values of $F(>0.05)$ for the analysis of variance for the mean volumetric diameter (MVD), droplet density (DEN), number of droplets (NOD), and droplet coverage (COV) as a function of spacing, angle, third, and interaction spacing $\times$ angle in the 2010/2011 season with the nozzle JA-2. Dourados, MS, Brazil. 2013.

\begin{tabular}{|c|c|c|c|c|c|}
\hline & DF & MVD & DEN & NOD & $\mathrm{COV}$ \\
\hline Spacing & 2 & $0.187^{\mathrm{ns}}$ & $0.395^{\mathrm{ns}}$ & $0.395^{\mathrm{ns}}$ & $0.311^{\mathrm{ns}}$ \\
\hline Residual & 3 & & & & \\
\hline Angle & 3 & $0.650^{\mathrm{ns}}$ & $0.050 *$ & $0.762^{\text {ns }}$ & $0.653^{\mathrm{ns}}$ \\
\hline Spacing $\times$ angle & 6 & $0.682^{\mathrm{ns}}$ & $0.028 *$ & $0.028 *$ & $0.740^{\mathrm{ns}}$ \\
\hline Residual & 9 & & & & \\
\hline Third & 2 & $0.011^{*}$ & $0.0001 *$ & $0.0001 *$ & $0.0001 *$ \\
\hline Spacing $\times$ third & 4 & $0.220^{\mathrm{ns}}$ & $0.3016^{\mathrm{ns}}$ & $0.3013^{\mathrm{ns}}$ & $0.2645^{\mathrm{ns}}$ \\
\hline Angle $\times$ third & 6 & $0.208^{\mathrm{ns}}$ & $0.0158 *$ & $0.0157^{*}$ & $0.0132 *$ \\
\hline Spacing $\times$ angle $\times$ third & 12 & $0.1058^{\mathrm{ns}}$ & $0.0228 *$ & $0.0223^{*}$ & $0.1545^{\mathrm{ns}}$ \\
\hline Residual & 96 & & & & \\
\hline
\end{tabular}

*Differ from each other by the F-test at 5\% probability. ${ }^{\text {ns }}$ Values do not differ from each other by the F-test at $5 \%$ probability.

TABLE 3. Mean volumetric diameter (MVD), droplet density (DEN), number of droplets (NOD), and droplet coverage (COV) as a function of spacing, angle, and third in the 2010/2011 season with the nozzle JA-2. Dourados, MS, Brazil. 2013.

\begin{tabular}{|c|c|c|c|c|}
\hline Spacing (m) & MVD & DEN & NOD & $\mathrm{COV}$ \\
\hline 0.22 & $191 \mathrm{a}$ & $142 \mathrm{a}$ & $167 \mathrm{a}$ & $9.8 \mathrm{a}$ \\
\hline 0.45 & $267 \mathrm{a}$ & $174 \mathrm{a}$ & $205 \mathrm{a}$ & $14.6 \mathrm{a}$ \\
\hline 0.90 & $170 \mathrm{a}$ & $167 \mathrm{a}$ & $196 \mathrm{a}$ & $9.3 \mathrm{a}$ \\
\hline Angle & MVD & DEN & NOD & $\mathrm{COV}$ \\
\hline $0^{\circ}$ & $172 \mathrm{a}$ & $162 \mathrm{~b}$ & $191 \mathrm{a}$ & $8.7 \mathrm{a}$ \\
\hline $30^{\circ}$ & $210 a$ & $186 \mathrm{a}$ & $218 \mathrm{a}$ & $13.3 \mathrm{a}$ \\
\hline $45^{\circ}$ & $259 a$ & $145 \mathrm{~b}$ & $171 \mathrm{a}$ & $12.1 \mathrm{a}$ \\
\hline $90^{\circ}$ & $197 \mathrm{a}$ & $151 \mathrm{~b}$ & $177 \mathrm{a}$ & $10.8 \mathrm{a}$ \\
\hline Third & MVD & DEN & NOD & COV \\
\hline Upper & $280 \mathrm{a}$ & $266 \mathrm{a}$ & $313 \mathrm{a}$ & $21.5 \mathrm{a}$ \\
\hline Middle & $193 a b$ & $154 \mathrm{~b}$ & $182 \mathrm{~b}$ & $9.4 \mathrm{~b}$ \\
\hline Lower & $155 \mathrm{~b}$ & $62 \mathrm{c}$ & $73 \mathrm{c}$ & $2.8 \mathrm{c}$ \\
\hline
\end{tabular}

*Means followed by the same lowercase letter in the column do not differ from each other by the Tukey's test at $5 \%$ probability.

Considering the interaction spacing $\times$ angle, the angle of $30^{\circ}$ presented the highest droplet density when compared to the angles of $45^{\circ}$ and $90^{\circ}$ in the interrow spacings of 0.22 and $0.45 \mathrm{~m}$. The lower third presented the lowest droplet density in relation to the upper and middle thirds for all angles of displacement. In the middle third, the angle of $30^{\circ}$ presented the highest droplet density, while in the upper third, the angle of $0^{\circ}$ of pesticide application presented the highest value (Table 3 ).

Droplet deposition in the middle and lower thirds is a very important characteristic in the application technology since it is influenced by the crop closing due to its growth. In this sense, an eight-year study evaluating the control of soybean rust found that the deposition is much higher in the 
upper third (Cunha et al., 2014b). However, the size of sprayed droplets influence their distribution in the plant canopy (Heidary et al., 2014) and spray tips that produce smaller droplets and a higher number of droplets assist in the penetration of droplets on leaves located in the lower parts of plants (Cunha et al., 2016).
The highest droplet density was obtained in the interrow spacing of $0.22 \mathrm{~m}$ in the upper third with an application angle of $0^{\circ}$. The lower third had the lowest values of droplet density regardless of the application angle in the interrow spacings of $0.22,0.45$, and $0.90 \mathrm{~m}$ (Table 3 ).

TABLE 4. Slicing of the interactions spacing $\times$ angle, angle $\times$ third, and spacing $\times$ angle $\times$ third for droplet density $(\mathrm{DEN})$ in the 2010/2011 season with the nozzle JA-2. Dourados, MS, Brazil. 2013.

\begin{tabular}{lccc}
\hline & & Spacing (m) & \\
\cline { 2 - 3 } Angle & $\mathbf{0 . 2 2}$ & $\mathbf{0 . 4 5}$ & $\mathbf{0 . 9 0}$ \\
$0^{\circ}$ & $149 \mathrm{AB}$ & $184 \mathrm{AB}$ & $155 \mathrm{~A}$ \\
$30^{\circ}$ & $194 \mathrm{~A}$ & $220 \mathrm{~A}$ & $143 \mathrm{~A}$ \\
$45^{\circ}$ & $121 \mathrm{~B}$ & $131 \mathrm{~B}$ & $183 \mathrm{~A}$ \\
$90^{\circ}$ & $104 \mathrm{~B}$ & $161 \mathrm{AB}$ & $187 \mathrm{~A}$ \\
\hline & & Third & Upper \\
Angle & Lower & Middle & $291 \mathrm{a} \mathrm{A}$ \\
$0^{\circ}$ & $51 \mathrm{c} \mathrm{A}$ & $145 \mathrm{~b} \mathrm{~B}$ & $278 \mathrm{a} \mathrm{AB}$ \\
$30^{\circ}$ & $62 \mathrm{~b} \mathrm{~A}$ & $217 \mathrm{a} \mathrm{A}$ & 219 a B \\
$45^{\circ}$ & $77 \mathrm{~b} \mathrm{~A}$ & $140 \mathrm{~b} \mathrm{~B}$ & $277 \mathrm{a} \mathrm{AB}$ \\
$90^{\circ}$ & $57 \mathrm{~b} \mathrm{~A}$ & $118 \mathrm{~b} \mathrm{~B}$ & \\
\hline
\end{tabular}

*Means followed by the same lowercase letter in the row and uppercase letter in the column do not differ from each other by the Tukey's at $5 \%$ probability.

The variable NOD in the angle of $90^{\circ}$ and $45^{\circ}$ presented the lowest values, differing from the application angle of $30^{\circ}$ in the spacing of $0.22 \mathrm{~m}$. In the interrow spacing of $0.45 \mathrm{~m}$, the highest value of NOD was found in the application angle of $30^{\circ}$. No difference for NOD was observed in the spacing of $0.90 \mathrm{~m}$ between the studied angles (Table 4).

The application angle of $0^{\circ}$ and $30^{\circ}$ presented the highest number of drops in the upper and middle thirds in the interrow spacing of 0.22 and $0.45 \mathrm{~m}$. The lower third had the lowest number of droplets in all application angles.
The number of drops in the lower part of plants is impaired due to the wall formed by the foliar mass, causing losses to agriculture related to the difficulty of controlling pests and diseases, leading to the need for new pesticide applications (Cavalieri et al., 2015).

The upper third had the highest averages of NOD for all application angles, not differing from the middle third only in the application angle of $30^{\circ}$. In the spacing of 0.90 $\mathrm{m}$, the application angles did not influence the number of drops, which presented the highest value in the upper third of plants.

TABLE 5. Slicing of the interactions spacing $\times$ angle, angle $\times$ third, and spacing $\times$ angle $\times$ third for the number of drops (NOD) in the 2010/2011 season with the nozzle JA-2. Dourados, MS, Brazil. 2013.

\begin{tabular}{|c|c|c|c|}
\hline \multirow[b]{2}{*}{ Angle } & \multicolumn{3}{|c|}{ Spacing (m) } \\
\hline & 0.22 & 0.45 & 0.90 \\
\hline $0^{\circ}$ & $175 \mathrm{a} A \mathrm{~B}$ & 216 a $\mathrm{AB}$ & $182 \mathrm{aA}$ \\
\hline $30^{\circ}$ & $228 \mathrm{ab} A$ & 259 a A & $168 \mathrm{~b} \mathrm{~A}$ \\
\hline $45^{\circ}$ & 143 a B & 154 a B & 215 a A \\
\hline \multirow[t]{2}{*}{$90^{\circ}$} & $122 \mathrm{~b} \mathrm{~B}$ & $190 \mathrm{ab} A B$ & 220 a A \\
\hline & \multicolumn{3}{|c|}{ Third } \\
\hline Angle & Lower & Middle & Upper \\
\hline $0^{\circ}$ & $51 \mathrm{c} \mathrm{A}$ & $145 \mathrm{~b} \mathrm{~B}$ & 291 a A \\
\hline $30^{\circ}$ & $62 \mathrm{~b} \mathrm{~A}$ & 217 a A & 278 a $\mathrm{AB}$ \\
\hline $45^{\circ}$ & $77 \mathrm{~b} \mathrm{~A}$ & $140 \mathrm{~b} \mathrm{~B}$ & 219 a B \\
\hline $90^{\circ}$ & $57 \mathrm{~b} \mathrm{~A}$ & $118 \mathrm{~b} \mathrm{~B}$ & 277 a $A B$ \\
\hline
\end{tabular}

*Means followed by the same lowercase letter in the row and uppercase letter in the column do not differ from each other by the Tukey's test at $5 \%$ probability. 
The droplet coverage was statistically equal in the three thirds of plants in the angles of $0^{\circ}$ and $30^{\circ}$. The upper third had a significant difference in the application angle of $45^{\circ}$ and $90^{\circ}$, differing from the middle and lower thirds in the angle of $45^{\circ}$ and from the lower third in the angle of $90^{\circ}$. Within the thirds of plants, the application angle did not influence the droplet coverage (Table 5).

The results within each spacing show that in the interrow spacing of $0.22 \mathrm{~m}$, the angle of $30^{\circ}$ presented the highest droplet coverage in the upper and middle thirds, while the angle of $45^{\circ}$ presented the worst result in relation to droplet deposition in the upper third of cotton plants. Droplet coverage presented the lowest value in the lower third of cotton plants with an interrow spacing of $0.22 \mathrm{~m}$.

These results show that producers should avoid choosing the angle of $45^{\circ}$ for the sprayer displacement. Several studies have worked with droplet size (Stoletniy et al., 2014), use of adjuvants (Tormen et al., 2012), types of spray tips, and plant architectures (Debortoli et al., 2012;
Cunha et al., 2017) as factors that influence droplet distribution. However, sprayer displacement in relation to crop rows is often not taken into account and placed as an uninfluenced factor of results on pesticide application quality. In this sense, this study shows that this factor influences the results of droplet distribution.

In the interrow spacings of 0.45 and $0.90 \mathrm{~m}$, the application angle of $45^{\circ}$ presented the highest coverage value mainly in the upper third. The quality of target coverage is related to the number and diameter of droplets and droplets with a smaller diameter are more likely to penetrate plant canopy (Graziano, 2017), causing a high variability of pesticide deposition along the application ranges, which reduces application effectiveness. The obtained results suggest that the number and density of droplets influenced droplet coverage values because the treatment with the application angle of $30^{\circ}$ presented the best results in relation to NOD, DEN, and COV.

TABLE 6. Slicing of the interaction angle $\times$ third for droplet coverage (COV) in the 2010/2011 season with the nozzle JA-2. Dourados, MS, Brazil. 2013.

\begin{tabular}{cccc}
\hline & & Third & \\
\hline Angle & Lower & Middle & Upper \\
\hline $0^{\circ}$ & $2.2 \mathrm{a} \mathrm{A}$ & $6.7 \mathrm{a} \mathrm{A}$ & $17.2 \mathrm{a} \mathrm{A}$ \\
$30^{\circ}$ & $2.9 \mathrm{a} \mathrm{A}$ & $17.7 \mathrm{a} \mathrm{A}$ & $19.4 \mathrm{a} \mathrm{A}$ \\
$45^{\circ}$ & $3.7 \mathrm{~b} \mathrm{~A}$ & $7.0 \mathrm{~b} \mathrm{~A}$ & $25.5 \mathrm{a} \mathrm{A}$ \\
$90^{\circ}$ & $2.3 \mathrm{~b} \mathrm{~A}$ & $6.2 \mathrm{ab} \mathrm{A}$ & $24.1 \mathrm{a} \mathrm{A}$ \\
\hline
\end{tabular}

*Means followed by the same lowercase letter in the row and uppercase letter in the column do not differ from each other by the Tukey's test at $5 \%$ probability.

The average number of droplets was lower in the interrow spacing of $0.22 \mathrm{~m}$. The upper third presented the highest average number of droplets in relation to the middle and lower thirds. The lower third, besides having the lowest average number of droplets, presented a value well below those found in other studies for the middle and upper thirds, showing that the adopted application model hinders droplet deposition in the lower third of plants (Table 6), regardless of the application angle and the interrow spacing (Cunha et al., 2014a; Sasaki et al., 2016).

TABLE 7. Average number of droplets as a function of spacing, angle, and third in the 2010/2011 season with the nozzle JA-2. Dourados, MS, Brazil. 2013.

\begin{tabular}{cc}
\hline Spacing (m) & Number of droplets \\
\hline 0.22 & $106.6 \mathrm{~b}$ \\
0.45 & $123.2 \mathrm{a}$ \\
0.90 & $141.0 \mathrm{a}$ \\
\hline Angle & $132.3 \mathrm{a}$ \\
\hline $0^{\circ}$ & $128.8 \mathrm{a}$ \\
$30^{\circ}$ & $112.1 \mathrm{a}$ \\
$45^{\circ}$ & $121.2 \mathrm{a}$ \\
\hline $90^{\circ}$ & \\
\hline Third & $213.7 \mathrm{a}$ \\
\hline Upper & $109.2 \mathrm{~b}$ \\
Middle & $48.0 \mathrm{c}$ \\
\hline Lower & \\
\hline
\end{tabular}

\footnotetext{
*Means followed by the same lowercase letter in the column do not differ from each other by the Tukey's test at $5 \%$ probability.
} 
Considering the application angles as a function of the third of cotton plants in each interrow spacing, the upper third provided the highest results for the variables DEN, NOD, and COV. These results demonstrate that, regardless of the analyzed characteristic, the lower third receives the least amount of pesticides during an application, which can lead to failures in the control of pests and diseases that have the habit of developing in the lower part of plants. The increase in interrow spacing was expected to favor droplet deposition and application technology features in the lower third of plants. Based on the results of this study, the largest interrow spacing did not influence application quality (Tables 7 and 8). Strategies such as an increase in the application volume or reduction in the droplet size can be used to increase droplet deposition in the lower third (Debortoli et al., 2012).

TABLE 8. Mean volumetric diameter (MVD), droplet density (DEN), number of drops (NOD), and droplet coverage (COV) as a function of spacing, angle, and third in the 2011/2012 season with the nozzle XR 110.02 VP. Dourados, MS, Brazil. 2013.

\begin{tabular}{|c|c|c|c|c|}
\hline Spacing (m) & MVD & DEN & NOD & $\mathrm{COV}$ \\
\hline 0.22 & $146 \mathrm{a}$ & $90 \mathrm{a}$ & $107 \mathrm{a}$ & $8.8 \mathrm{a}$ \\
\hline 0.45 & $171 \mathrm{a}$ & $104 \mathrm{a}$ & $123 \mathrm{a}$ & $12.7 \mathrm{a}$ \\
\hline 0.90 & $146 \mathrm{a}$ & $119 a$ & $141 \mathrm{a}$ & $11.4 \mathrm{a}$ \\
\hline \multicolumn{5}{|l|}{ Angle } \\
\hline $0^{\circ}$ & $157 \mathrm{a}$ & $112 \mathrm{a}$ & $132 \mathrm{a}$ & $13.3 \mathrm{a}$ \\
\hline $30^{\circ}$ & $153 \mathrm{a}$ & $109 a$ & $129 \mathrm{a}$ & $10.3 \mathrm{a}$ \\
\hline $45^{\circ}$ & $156 \mathrm{a}$ & $95 \mathrm{a}$ & $112 \mathrm{a}$ & $10.4 \mathrm{a}$ \\
\hline $90^{\circ}$ & $151 \mathrm{a}$ & $102 \mathrm{a}$ & $121 \mathrm{a}$ & $9.9 \mathrm{a}$ \\
\hline \multicolumn{5}{|l|}{ Third } \\
\hline Upper & $176 \mathrm{a}$ & $181 \mathrm{a}$ & $213 a$ & $22.2 \mathrm{a}$ \\
\hline Middle & $147 \mathrm{~b}$ & $93 \mathrm{~b}$ & $109 \mathrm{~b}$ & $7.7 \mathrm{~b}$ \\
\hline Lower & $138 \mathrm{~b}$ & $40 \mathrm{c}$ & $48 \mathrm{c}$ & $2.9 \mathrm{c}$ \\
\hline
\end{tabular}

*Means followed by the same lowercase letter in the column do not differ from each other by the Tukey's test at $5 \%$ probability.

The open area in the interrow on the day of application had a significant statistical difference in relation to spacing. Because the treatments with interrow spacings were twice the size of the other treatment, i.e. $0.22,0.45$, and $0.90 \mathrm{~m}$, the possibility of the open area be larger in the spacing of $0.90 \mathrm{~m}$ was expected. On the day of application, the treatment with a spacing of $0.22 \mathrm{~m}$ presented all the leaves interlaced, without the presence of free area in the interrow of plants. The average spacing without the presence of leaves was $26.5 \mathrm{~cm}$ in the interrow spacing of $0.90 \mathrm{~m}$ (Table 9).
The study of the open area in the interrow assists in understanding some characteristics of the application quality. Droplet deposition in the middle and lower thirds are influenced by MVD and the lack of physical barriers that hinders the passage of spray droplets in the lower third of plants. In the spacing of $0.90 \mathrm{~m}$, the possibility of droplets reaching the leaves of the lower third is higher when compared to the interrow spacings of 0.22 and $0.45 \mathrm{~m}$. This assumption takes into account only the physical barriers, not considering application quality, such as the number of drops produced, droplet size, nozzle type, and application volume.

TABLE 9. Open area as a function of spacing, angle, and interaction spacing $\times$ angle in the 2011/2012 season with the nozzle XR 110.02 VP. Dourados, MS, Brazil. 2013.

\begin{tabular}{cc}
\hline Spacing $(\mathbf{m})$ & Open area (cm) \\
\hline 0.22 & $0.0 \mathrm{c}$ \\
0.45 & $8.13 \mathrm{~b}$ \\
0.90 & $26.5 \mathrm{a}$ \\
\hline
\end{tabular}

*Means followed by the same lowercase letter in the column do not differ from each other by the Tukey's test at 5\% probability.

\section{CONCLUSIONS}

- The application angle of $30^{\circ}$ in relation to the sowing row presented the highest values in relation to the number and density of droplets.

- In the ultra-narrow row system, the upper third of plants received the highest number of droplets, droplet density, and droplet coverage when compared to the middle and lower thirds.

\section{REFERENCES}

Borin ALDC, Ferreira ACB, Sofiatti V, Carvalho MCS, Moraes MCG (2017) Produtividade do algodoeiro adensado em segunda safra em resposta a adubação nitrogenada e potássica. Revista Ceres 64(6):622-630 DOI: http://dx.doi.org/10.1590/0034-737x201764060009

Cavalieri JD, Raetano CG, Madureira RP, Moreira LLQ (2015) Spraying systems and traveling speed in the deposit and spectrum of droplets in cotton plant. Engenharia Agrícola 35(6):1042-1052. DOI: http://dx.doi.org/10.1590/1809-4430Eng.Agric.v35n6p1042-1052/2015 
Conab (2018) Acompanhamento da safra brasileira 5(8):48-50.

Cunha JPAR, Juliatti FC, dos Reis EF (2014a) Tecnologia de aplicação de fungicida no controle da ferrugem asiática da soja: resultados de oito anos de estudos em Minas Gerais e Goiás. Bioscience Journal 30(4):950-957. DOI: http://www.seer.ufu.br/index.php/biosciencejournal/article/ viewFile/20907/14739

Cunha JPAR, Moura EAC, Juliatti FC, Reis EF (2014b) Tecnologia de aplicação de fungicida no controle da ferrugem asiática da soja: resultado de oito anos de estudo em Minas Gerais. Bioscience Journal 30(4):950-957.

Cunha JPAR, Victor AP, Sales CGR (2018) Spray deposition on soybean crop using different travel speeds and application rates. Engenharia Agrícola 38 (1): 82-87. DOI: http://dx.doi.org/10.1590/1809-4430-

Eng.Agric.v38n1p82-87/2018

Cunha JPAR, Barizon RRM, Ferracini VL, Assalin MR (2017) Spray drift and caterpillar and stink bug control from aerial applications with electrostatic charge and atomizer on soybean crop. Engenharia Agrícola 37(6):1163-1170. DOI:

http://www.scielo.br/pdf/eagri/v37n6/1809-4430-eagri-3706-1163.pdf

Cunha JPAR, Marques RS, Alves GS (2016) Deposição da calda na cultura da soja em função de diferentes pressões de trabalho e pontas de pulverização. Revista Ceres 63(6):761-768. DOI: http://dx.doi.org/10.1590/0034$737 \times 201663060003$

Cunha JPAR, Moura EAC, Silva Junior JL, Zago FA, Juliatti FC (2008) Efeito de pontas de pulverização no controle químico da ferrugem da soja. Engenharia Agrícola 28(2):283-291. DOI: http://dx.doi.org/10.1590/S0100-69162008000200009

Debortoli MP, Tormen NR, Balardin RS, Favera DD, Stefanello MT, Pinto FF, Uebel JD (2012) Espectro de gotas de pulverização e controle da ferrugemasiáticadasoja em cultivares com diferentes arquiteturas de planta. Pesquisa agropecuária brasileira 47(7):920-927. DOI: http://www.scielo.br/pdf/pab/v47n7/47n07a07.pdf

Embrapa Agropecuária Oeste (2011) Produção sustentável de algodão. Dourados, $27 \mathrm{p}$.
França JAL, Cunha JPAR, Antuniassi UR (2018) Spectrum and velocity of droplets of spray nozzles with and without air induction. Engenharia Agrícola 38(2):232237. DOI: http://dx.doi.org/10.1590/1809-4430Eng.Agric.v38n2p232-237/2018

Graziano CEPL, Alves KA, Gandolfo MA, Dario G, Oliveira RB (2017) Spraying quality of crop protection products using two droplet spectra in three periods of the day. Engenharia Agrícola 37(6):1183-1189. DOI: http://dx.doi.org/10.1590/1809-4430Eng.Agric.v37n6p1183-1189/2017

Heidary MA, Douzals JP, Sinfort C, Vallet A (2014) Influence of spray characteristics on potential spray drift of field crop sprayers: A literature review. Crop protection 63(1):120-130. DOI:

https://doi.org/10.1016/j.cropro.2014.05.006

Stoletniy I, Olivet J, Villalba J (2014) Tamaño de gota, volumen de aplicación y uso de adyuvante en la deposición y control de mancha amarilla (Pyrenophora tritici-repentis) en trigo. Agrociencia Uruguay 18(1):97-114.

Marur CJ, Ruano O (2001) A reference system for determination of developmental stages of upland cotton. Revista Brasileira de Oleaginosas e Fibrosas 5(1):313-317.

Rosolem CA, Echer FR, Lisboa IP, Barbosa TL (2012) Acúmulo de nitrogênio, fósforo e potássio pelo algodoeiro sob irrigação cultivado em sistema convencional e adensado. Revista Brasileira de Ciências do Solo 36(2). DOI: http://dx.doi.org/10.1590/S010006832012000200015

Sasaki RS, Teixeira MM, Fernandes HC, Zolnier S, Maciel CFS, Alvarenga CB (2016) Dropltes spectrum or airassisted boom sprayers under different environmental and operational conditions. Revista Brasileira de Engenharia Agrícola 20(1):92-96. DOI: http://dx.doi.org/10.1590/18071929/agriambi.v20n1p92-96

Tormen NR, Silva FDL, Debortoli MP, Uebel JD, Favera DD, Balardin RS (2012) Deposição de gotas no dossel e controle químico de Phakopsora pachyrhizi na soja. Revista Brasileira de Engenharia Agrícola e Ambiental 16(7):802-808. 